\title{
Potensi Ekstrak Daun Teh Hijau terhadap Morfologi dan Motilitas Spermatozoa Tikus Putih (Rattus norvegicus) setelah Paparan Asap Rokok
}

\author{
Tri Panjiasih Susmiarsih ${ }^{1 *}$, Kenconoviyati $^{2}$, Kuslestari $^{2}$ \\ ${ }^{1}$ Bagian Biologi Fakultas Kedokteran Universitas YARSI, Jakarta \\ ${ }^{2}$ Bagian Hisiologi Fakultas Kedokteran Universitas YARSI, Jakarta \\ *Korespondensi Email: susmiarsih@gmail.com
}

\begin{abstract}
Abstrak
Asap rokok mengandung bahan kimia berbahaya dan radikal bebas yang berpotensi menimbulkan infertilitas. Radikal bebas dapat dinetralisir dengan pemberian antioksidan alami seperti Teh (Camelia sinensis) karena daun teh hijau banyak mengandung polifenol flavonoid katekin yang diduga senyawa ini berfungsi sebagai antioksidan.Tujuan penelitian ini adalah mengetahui potensi ekstrak daun teh hijau terhadap morfologi dan motilitas spermatozoa tikus (Rattus norvegicus) setelah paparan asap rokok. Penelitian ini menggunakan 24 ekor tikus putih yang terbagi atas 8 kelompok (K1,P1,P2,P3, K2,P4,P5,P6 dengan waktu paparan 30 dan 45 hari. $\mathrm{K} 1$ dan $\mathrm{K} 2$ adalah kontrol, P1 dan P5 adalah kelompok yang terpapar asap rokok (1 batang per hari) dan diberi ekstrak teh hijau (200 $\mathrm{mg} / \mathrm{kg} \mathrm{bb}$ ). P2 dan P5 adalah kelompok yang dipapar asap rokok. P3 dan P6 adalah kelompok yang diberi ekstrak teh hijau. Spermatozoa diambil dari kauda epididimis. Analisis data menggunakan uji ANOVA dan uji perbandingan LSD. Hasil penelitian menunjukkan ekstrak daun teh hijau secara bermakna $(p<0.05)$ dapat meningkatkan motilitas spermatozoa tikus setelah paparan asap rokok, sedang ekstrak daun teh hijau tidak dapat meningkatkan morfologi normal spermatozoa setelah paparan asap rokok.
\end{abstract}

Kata Kunci : teh hijau, spermatozoa, rokok

\begin{abstract}
Cigarette smoke contains dangerous chemicals and free radicals that cause infertility. Free radicals can be neutralized by giving natural antioxidants such as green tea leaves (Camelia sinensis)containing a lot of catechin flavonoid polyphenols as antioxidants. This study determine the effect of green tea leaf extract on the number and motility of spermatozoa rats (Rattus norvegicus) after exposure to cigarette smoke. This study used 24 white rats that divided into 8 groups (K1,P1, P2, $P 3, K 2, P 4, P 5, P 6$ with exposure times of 30 and 45 days. $K 1$ and $K 2$ were controls, $P 1$ and $P 5$ were groups exposed to smoke cigarettes and given green tea extract $P 2$ and $P 5$ were the groups exposed to cigarette smoke $P 3$ and P6 were the group given green tea extract. Dose of cigarette smoke exposure was 1 bar per day and green tea leaf extract $200 \mathrm{mg} / \mathrm{kg}$ bb. Spermatozoa was taken from cauda epididymis. Data analysis of morhology and motility spermatozoa used ANOVA and LSD
\end{abstract}


comparison test.The results showed that green tea leaf extract increased significantly sperm motility of rat after cigarette smoke exposure, but not increase morphology sperm.

Keywords: green tea, spermatozoa, cigarettes

\section{Pendahuluan}

Di Indonesia, salah satu penyebab utama terjadinya sakit diantara penduduk miskin dan lebih dari $97 \%$ orang tidak merokok akibat terpapar asap rokok (Barber et al. 2008). Asap rokok mengandung bahan kimia berbahaya dan radikal bebas yang berpotensi menimbulkan infertilitas. Asap rokok mengandung senyawasenyawa sumber radikal bebas terbesar yaitu: tar, nikotin, karbonmonoksida dan PAH (Polynuclear Aromatic Hydrogen), senyawa-senyawa ter- sebut dapat menyebabkan infertilitas dengan ditandai penurunan parameter dan fungsi semen dan kematian spermatozoa (Roychoudhury et al. 2017). Asap rokok mengandung berbagai bahan kimia antara lain nikotin, karbon monoksida, tar dan lain-lain sehingga efek bahan kimia tersebut ternyata dapat menganggu kualitas dan kuantitas (jumlah, motilitas dan morfologi) spermatozoa epididimis dan menyebabkan kerusakan sel-sel testis. Nikotin menyebabkan penurunan motilitas dan jumlah sperma (Oyeyipo et al. 2011). Radikal bebas menyebabkan kerusakan integritas DNA spermatozoa hingga kematian sel. ROS yang timbul karena asap rokok berpengaruh terhadap fungsi sel Sertoli dan sel Leydig di testis dan menyebab-kan gangguan kualitas spermatozoa.

Radikal bebas asap rokok dapat dinetralisir dengan pemberian antioksidan eksogen seperti superoksida dismutase, katalase, glutation peroksidase, vitamin A, D, E, dan $C$, namun penggunaan antioksidan tersebut masih terkendala oleh keterbatasan bahan dan harga yang tidak terjangkau oleh masyarakat. Untuk itu dicari antioksidan yang berasal dari tumbuhan yang banyak dibudidayakan di Indonesia, diantaranya daun teh hijau, yang sering dikonsumsi oleh masyarakat. Daun teh hijau mengandung flavonoid katekin, terutama Daun teh hijau mengandung flavonoid katekin, terutama epigallocatechin-3-gallate, yang bermanfaat bagi kesehatan (Chako et al. 2010; Suzuki et al. 2016).

Jenis-jenis katekin yang ditemukan dalam teh hijau diantaranya epicatechin (EC), epicatechin-2-gallate (ECG), epigallocatechin (EGC) dan epigallocatechin-3-gallate (EGCG). EGCG merupakan katekin terbanyak (sekitar 50$80 \%$ dari katecin total) (Namita et al. 2012). Katekin berfungsi sebagai antioksidan yang dapat menurunkan radikal bebas (Chako et al. 2010; Suzuki et al. 2016).

Dari uraian di atas, daun teh hijau mempunyai prospek sebagai bahan antioksidan alami potensial dalam memperbaiki kualitas spermatozoa akibat paparan radikal bebas sehingga perlu diteliti pengaruh pemberian ekstrak daun teh hijau terhadap morfologi dan motilitas spermatozoa tikus (Rattus norvegicus) setelah paparan asap rokok.

\section{Bahan dan Metoda Penelitian}

Jenis penelitian ini adalah eksperimental laboratorium yang dikerjakan pada Laboratorium Biologi, Biokimia dan Laboratorium Terpadu 
Universitas YARSI. Daun teh hijau diambil dari daerah Bogor dan diekstraksi menggunakan metode maserasi.

Penelitian menggunakan 24 ekor tikus putih galur Wistar (Rattus novergicus), yang dibagi atas 8 kelompok. Periode perlakuan selama 30 hari yaitu:

- kelompok kontrol (K1)

- kelompok paparan asap rokok dan pemberian ekstrak teh hijau (P1)

- kelompok paparan asap rokok (P2)

- kelompok pemberian ekstrak teh hijau (P3)

Periode perlakuan selama 45 hari yaitu :

- kelompok kontrol (K2)

- kelompok paparan asap rokok dan pemberian ekstrak teh hijau (P4)

- kelompok paparan asap rokok (P5)

- kelompok pemberian ekstrak teh hijau (P6)

Paparan asap rokok sebanyak 1 batang per hari dan ekstrak daun teh hijau sebanyak $200 \mathrm{mg} / \mathrm{kg}$ bb. Semen diperoleh dari epididimis bagian kaudal. Parameter penelitian yang diukur adalah morfologi dan motilitas spermatozoa.

Morfologi sperma dihitung dengan cara $10 \mu$ spermatozoa dari kauda epididimis dicampur $1 \mathrm{ml} \mathrm{NaCl}$ 0,9\%, diambil $10 \mu \mathrm{l}$ suspensi sperma dan dicampur merata dengan $10 \mu$ larutan $2 \%$ eosin $\mathrm{Y}$, letakkan pada gelas objek dan dihitung persentase morfologi normal (spermatozoa tidak berwarna merah) dari 100 spermatozoa.Motilitas diukur dengan cara $10 \mu \mathrm{l}$ spermatozoa dari kauda epididimis dicampur 1 $\mathrm{ml} \mathrm{NaCl} \mathrm{0,9 \% ,} \mathrm{dicampur} \mathrm{merata,} \mathrm{ambil} 10 \mu \mathrm{l}$ suspensi, letakkan pada gelas objek dan dihitung persentase spermatozoa dengan motilitas normal progresif dan bergerak tidak ditempat di bawah mikroskop dengan perbesaran 400x. Analisis data konsentrasi dan kecepatan spermatozoa menggunakan uji ANOVA.

\section{Hasil Penelitian}

Hasil pengamatan terhadap morfologi spermatozoa tikus putih yang diberi beberapa perlakuan asap rokok dan ekstrak daun teh hijau dapat dilihat pada Tabel 1.

Pada Tabel 1, persentase morfologi sperma tikus kelompok P2 dan P5 yang mendapat paparan asap rokok $(54.50 \%$ dan $44,07 \%)$ lebih rendah dibandingkan motilitas sperma tikus kontrol kelompok K1 dan K2 (79,20\% dan $81.57 \%)$. Hasil uji statistik menunjukkan bahwa morfologi normal sperma tikus secara bermakna tidak dapat ditingkatkan dengan pemberian teh hijau setelah paparan asap rokok $(p=0.41)$ yaitu kelompok $P 1 \quad(58.40 \%)$ dan kelompok (51.20\%). Pada Tabel 2, persentase motilitas sperma tikus kelompok P2 dan P5 yang mendapat paparan asap rokok (59.92\% dan 52,73\%) lebih rendah dibandingkan motilitas sperma tikus kontrol kelompok $\mathrm{K} 1$ dan K2 (74,33\% dan $75.77 \%)$. Hasil uji statistik menunjukkan bahwa motilitas sperma tikus secara bermakna dapat ditingkatkan dengan pemberian teh hijau setelah paparan asap rokok ( $p=0.037)$ yaitu kelompok P1 (68.75\%) dan kelompok (69.07\%). 
Tabel 1. Morfologi Normal Spermatozoa Tikus Putih Galur Wistar (Rattus norvegicus) setelah Paparan Asap Rokok dan Ekstrak Daun Teh Hijau

\begin{tabular}{ccccc}
\hline $\begin{array}{c}\text { Waktu } \\
\begin{array}{c}\text { Perlakuan } \\
\text { (hari) }\end{array}\end{array}$ & \multicolumn{4}{c}{ Morfologi Normal SpermatozoaTikus Putih (\%) } \\
\cline { 2 - 5 } & $\mathbf{( K 1 )}$ & $\mathbf{( P 1 )}$ & $\mathbf{( P 2 )}$ & $\mathbf{( P 3 )}$ \\
\hline \multirow{2}{*}{30} & 70,6 & 58,4 & 54,5 & 72.4 \\
& 84,5 & 60.2 & 48.8 & 83.4 \\
& 82,5 & 48.4 & 52.4 & 85.2 \\
\hline Rata-rata & 79.20 & 58.40 & 54.50 & 80.33 \\
\hline & $(\mathbf{K 2})$ & $\mathbf{( P 4 )}$ & $\mathbf{( P 5 )}$ & $\mathbf{( P 6 )}$ \\
\hline & 80,8 & 50,6 & 40,2 & 79,6 \\
& 76,5 & 47,5 & 44,5 & 79,5 \\
\hline Rata-rata & 81,57 & 55,5 & 47,5 & 84,5 \\
\hline $\mathrm{p}=0.41$ & 87,4 & 51,20 & 44,07 & 81,20 \\
\hline
\end{tabular}

Tabel 2. Motilitas Spermatozoa Tikus Putih Galur Wistar (Rattus norvegicus) setelah Paparan Asap Rokok dan Ekstrak Daun Teh Hijau

\begin{tabular}{ccccc}
\hline $\begin{array}{c}\text { Waktu } \\
\begin{array}{c}\text { Perlakuan } \\
\text { (hari) }\end{array}\end{array}$ & \multicolumn{4}{c}{ Motilitas SpermatozoaTikus Putih (\%) } \\
\cline { 2 - 5 } & $\mathbf{( K 1 )}$ & $\mathbf{( P 1 )}$ & $\mathbf{( P 2 )}$ & $\mathbf{( P 3 )}$ \\
\hline \multirow{2}{*}{30} & 78.21 & 64.45 & 60.69 & 72.91 \\
& 71.15 & 73.36 & 59.21 & 74.33 \\
& 73.63 & 68.43 & 59.87 & 77.73 \\
\hline Rata-rata & 74.33 & 68.75 & 59.92 & 74.99 \\
\hline & $(\mathbf{K 2})$ & $\mathbf{( P 4 )}$ & $\mathbf{( P 5 )}$ & $\mathbf{( P 6 )}$ \\
\hline \multirow{2}{*}{45} & 76.08 & 68.60 & 49.57 & 77.78 \\
& 78.20 & 73.27 & 57.87 & 86.94 \\
\hline Rata-rata & 72.91 & 65.33 & 50.74 & 68.48 \\
\hline $\mathrm{p}=0.037$ & 75.77 & 69.07 & 52.73 & 77.73 \\
\hline
\end{tabular}

Diskusi

Morfologi merupakan salah satu faktor penting yang diperlukan dalam menunjang kemampuan fertilisasi spermatozoa. Fertilisasi akan terjadi apabila spermatozoa memiliki bentuk yang normal. Hanya spermatozoa normal yang mampu membuahi sel telur. Walaupun jumlah spermatozoa seseorang normal, namun apabila morfologinya terganggu akan 
berpengaruh terhadap rendahnya kemampuan fungsional spermatozoa (Heni, 2011).

Hasil penelitian menunjukkan bahwa morfologi normal sperma tikus secara bermakna tidak dapat diperbaiki dengan pemberian teh hijau setelah paparan asap rokok. Hasil ini tidak sejalan dengan beberapa penelitian lain dimana ekstrak daun teh hijau terbukti dapat memperbaiki spermatozoa karena mengandung flavonoid yang merupakan metabolit sekunder yang memiliki aktivitas antioksidan paling tinggi yaitu 20 kali lebih tinggi dari pada vitamin C (Siburian, et al., 2015). Flavonoid akan menangkap radikal bebas dengan melepaskan atom hidrogen dari gugus hidroksilnya dan memutus reaksi berantai dari radikal bebas (Almatsier, 2004). Katekin merupakan golongan flavonoid yang memiliki kemampuan untuk menangkal radikal bebas dan logam transisi chelate, yang membantu mengurangi tingkat stress oksidatif (Hijazi, et al., 2015). Hasil yang berbeda ini dapat disebabkan dosis paparan asap rokok cukup tinggi dan waktu paparan cukup lama akibatnya tingkat kerusakan sel tinggi sehingga pemberian ekstrak daun teh belum dapat mencegah kerusakan morfologi sperma.

Rokok merupakan salah satu penyebab kerusakan sel karena dalam rokok mengandung bahan yang dapat membentuk radikal bebas. Kelebihan produksi radikal bebas atau oksigen yang reaktif (ROS, reactive oxygen species) dapat merusak sperma. ROS menjadi salah satu penyebab infertilitas karena anion superoksida, radikal hidroksil dan hidrogen peroksida merupakan radikal bebas utama yang ditemukan pada plasma semen infertil (Agarwal et al, 2003). Asap rokok dapat meningkatkan ROS dan menurunkan antioksidan di cairan semen sehingga seorang perokok lebih rentan mengalami infertilitas (Agarwal dan Said, 2005) melalui penurunan motilitas, peningkatan kerusakan membran, penurunan morfologi normal, viabilitas, dan kemampuan spermatozoa (Twig et al., 1998).

Merokok diketahui dapat meningkatkan level radikal bebas yang memicu perusakan DNA dan berbagai basa teroksidasi. merokok juga dapat menyebabkan oksidasi glutation (GSH, antioksidan yang melindungi DNA dari kerusakan akibat ROS), menurunkan level antioksidan dalam darah, dan meningkatkan pelepasan radikal superoksida (Ziech, et al., 2011). Paparan terhadap asap rokok memiliki relasi yang kuat dengan kerusakan DNA yang dipicu oleh radikal oksidatif (oxidative stress) dan karsinogenesis (Patel, et al., 2008). Radikal bebas dalam jumlah berlebihan, sementara jumlah antioksidan seluler lebih sedikit, maka kondisi ini dapat menyebabkan kerusakan sel. Kerusakan sel inilah yang diduga menjadi penyebab penurunan motilitas sperma.

Asap rokok akan meningkatkan jumlah lipid peroksidasi dan menimbulkan kerusakan serta penurunan integritas membran spermatozoa sehingga mengurangi motilitas. Radikal bebas juga dapat menurunkan frekuensi gerakan ekor spermatozoa karena radikal bebas menyebabkan produksi ATP mitokondria menjadi rendah. Mitokondria merupakan tempat proses perombakan atau katabolisme untuk menghasilkan energi bagi pergerakan ekor spermatozoa (Fitriani et al., 2010). Dari hasil penelitian, penurunan motilitas spermatozoa terbukti dapat diperbaiki dengan pemberian ekstrak daun teh hijau.

Antioksidan dari teh hijau dapat mencegah kerusakan oksidatif akibat radikal bebas pada beberapa parameter sperma seperti motilitas, abnormalitas dan konsentrasi (Sheteifa 
dan Morsy, 2014). Penelitian yang dilakukan oleh Abshenas et al. (2012) juga membuktikan adanya efek terapi dari ekstrak teh hijau terhadap kerusakan kualitas semen akibat hipertermia. Selain itu, pemberian ekstrak teh hijau selama 28 hari secara signifikan meningkatkan motilitas, konsentrasi dan integritas membran sperma akibat adanya senyawa polifenol dari teh hijau yang memiliki sifat antioksidan kuat. Antioksidan dari teh dapat menurunkan risiko kerusakan stress oksidatif dan peningkatan kapasitas antioksidan dalam sel untuk menangkap radikal bebas yang dapat menghambat terjadinya kerusakan pada membran sel (Awoniyi, 2010; Chaturvedula dan Prakash, 2011).

\section{Simpulan}

Pemberian ekstrak daun teh hijau tidak dapat memperbaiki morfologi spermatozoa tikus putih setelah paparan asap rokok namun dapat meningkatkan motilitas spermatozoa semen tikus putih.

\section{Daftar Pustaka}

Abshenas J, Babaei H, Zare MH, Allahbakhshi A, Sharififar F. The effects of grees tea (Camillia sinensis) extract on mouse semen quality after scrotal heat stress. Veternity Research Forum. 2011:242-247

Agarwal A, Said TM. Oxidative stress, DNA damage and apoptosis in male infertility; a clinical approach. International Brazilian Journal of Urology, 2005:95, 503-507.

Agarwal A, Saleh RA, Bedaiway MA. Role of reactive species in the pathophysiology of human reproduction Fertil Steril. Journal Reproduction.2003;(79):839-43.

Awoniyi DO. The role of rooibos (aspalathus linearis), green tea (camellia sinensis) and commercially available rooibos and green tea antioxidant supplements on rat testicular and epididymal function. Thesis. 2010. Faculty of Health and Wellness Sciences. Cape Peninsula University of Technology.

Chako SM, Thambi PT, Kuttan R, Nishigaki I. Beneficial effects of green tea: A literature review. Chinese Medicine. 2010: 5:13.

Chaturvedula VSP, Prakash I. The aroma, taste, color and bioactive constituents of tea. Journal of Medicinal Plants Research. 2011:5(11): 2110-2124.

Fitriani, Eriani K, Sari W. The Effect Of Cigarettes Smoke Exposured Mus Musculus). Jurnal Natural. 2010:10(2);1516.

Heni S. Kesesuaian hasil pemeriksaan morfologi spermatozoa antara pulasan giemsa, meyer, dan o.steeno dari pria pasangan usia subur. The Journal of Andrology Indonesia. 2011;8(38):12-8Namita P, Mukesh R, Vijay KJ. 2012. Camellia Sinensis (Green Tea): A Review. Global Journal of Pharmacology 6 (2): 52-59.

Oyeyipo IP, Raji Y, Emikpe BO, Bolarinwa AF. Effects of nicotine on sperm characteristics and fertility profile in adult male rats: a possible role of cessation. J Reprod Infertle. 2011:12(3):201-207.

Patel BP, Rawal UW. Tobacco, antioxidant enzymes, oxidative stress, and genstic susceptibility in oral cancer. Am.J. Clin.Oncol. 2008:31: 454-459.

Roychoudhury S, Agarwal A, Virk G, Lam Cho C. Potential role of green tea catechins in the management of oxidative stressassociated infertility. Reproductive 
BioMedicine. 2017 doi: 10.1016/ j.rbmo.2017.02.006

Sheteifa MAM, Morsy WA. Effect of green tea as dietary supplements (Camellia sinensis) on semen quality and testosterone. profile in rabbits J. Animal and Poultry Prod., Mansoura Univ. 2014:.5 (1): 1 - 13

Suzuki $T$, Pervin $M$, Goto $S$, Isemura $M$, Nakamura, Y. 2016. Beneficial Effects of Tea and the Green Tea Catechin Epigallocatechin-3-gallate on Obesity. Molecules. 2016: 21, 1305:1-13.

Twigg J, Fulton N, Gomez E, Irvine DT, Aitken RJ. Analysis of the impact of intracellular reactive oxygen species generation on structural and functional integrity of human spermatozoa: lipid peroxidation, DNA fragmentation and effectiveness of antioxidants. Human Reproduction, 1998:13, 1429-36.

Yang CS, Chung JY, Yang G, Chhabra SK, Lee MJ. Tea and Tea Polyphenols in Cancer Prevention. Symposium: Diet, Natural Products and Cancer Prevention: Progress and Promise Supplement. American Society for Nutritional Sciences. 2000:478S

Ziech D, Franco R, Pappa A, Panayjiotidis, MI. Reactive Oxygen Species (ROS) Induced Genetic and Epigenetic. Alterations in Human Carcinogenesis. Mutation Research. 2011: 711: 167-173. 